\title{
Capacity building with a difference
}

\author{
Sam Gumbo \\ Computer Educational Services \\ Box MP 139, Mt. Pleasant \\ Harare, Zimbabwe \\ Tele + 263-4-781022; Fax + 263-4-781022
}

\begin{abstract}
Information Technology (IT) has come to the classroom faster than most Ministries of Education in developing countries ever anticipated, resulting in ad hoc approaches to the implementation of IT in the school system. The major problems have been the lack of prerequisites to successful integration of IT in the school curriculum, for example a lack of qualified teachers, a lack of understanding of what curriculum to teach and whom to teach in the face of so many pupils in one school with limited equipment.

The Zimbabwe Midlands Information Technology in Education Project (ZiMITEP) is a pilot research project which is meant to lay a foundation for a systematic implementation of IT in schools in developing countries. The pilot project focuses on factors that have been identified as constraints to the introduction of IT in the schools' curriculum including: trained personal; technical support; and appreciation of IT in education. The pilot project seeks to: identify appropriate IT implementation strategies in developing countries; bring together, coordinate and harmonize IT activities in the schools; cooperate with other local and outside organizations for the purpose of exchanging ideas and share experience; promote and coordinate in-service training for teachers in IT education in Zimbabwe; provide possible solutions to problems experienced in the introduction of IT in developing countries; and provide a foundation for IT policy in schools.
\end{abstract}

\section{Keywords}

Case studies, curriculum policies, distance learning, resources, teaching materials

Capacity Building for IT in Education in Developing Countries

G. Marshall \& M. Ruohonen (Eds.)

(C) 1998 IFIP. Published by Chapman \& Hall 
Information technology (IT) has become a reality in developing countries. However, IT has come to the classroom environment faster than most governments anticipated, resulting in ad hoc approaches to IT's integration into the school curriculum. Schools that find themselves with computers donated or purchased by parents have been faced with numerous problems in their endeavours to introduce IT into the school system. Many of the problems are related to the shortage of trained teachers and technicians. The lack of adequate and appropriate hardware and software also creates difficulties. The situation is made worse by lack of national policies to guide schools in what to teach and how to teach.

In Zimbabwe today only $1.6 \%$ of the 6187 primary and secondary schools have computers. The activities in the computer-equipped schools vary from computer clubs to formal examination classes. The three common syllabi being taught in the ' $O$ ' level classes are Pitman, Cambridge Computer Studies Syllabus or the Zimbabwe National Foundation Certificate, which is examined by the Ministry of Higher Education Examination Council (HEXCO). The choice of what to teach depends on the school, the availability of computer equipment and the qualifications of the IT teacher. One of the major problems in Zimbabwe schools is the lack of appropriate and adequate hardware and software.

\section{Hardware}

The number of computers in the schools ranges from one to 20 per school. Since most of the computers are donated, the schools do not have an opportunity to request computers which meet the requirements of the schools in terms of numbers, type and capacity. Some of the computers are not compatible with other computers in the same school. However, a few schools have the state-of-the-art computers.

\section{Software}

Most schools have application software. In addition, some schools have software for teaching the English language, mathematics, science and the social sciences classes. Most of the software was not developed for the African child and the African environment. More still needs to be done in this area.

\section{Teacher Training}

Zimbabwe has two teachers' colleges that train computer teachers. Other teachers' training colleges which have computers have not yet established a teacher training component into their curriculum.

Computer Educational Services, a private company has taken an initiative to provide an in-service Information Technology course for teachers called 'Computers in Education', which has been very successful. The first group of teachers trained, from all over Zimbabwe, graduated in 1997. This is a distance and open learning programme. 
The University of Zimbabwe Centre for Distance Education also offers a component of Information Technology to the Bachelor of Education Administration students. The majority of students enrolled in the Bachelor of Education Administration programme are teachers. The University of Zimbabwe, the National University of Science and Technology and Selous University also produce computer science graduates, some of whom end up in the classroom teaching computer studies.

Human resources may not be a major problem but a national policy is required so that teacher training may be focused on relevant curriculum. It is critical that pilot projects be carried out to guide policy formulation and implementation strategies.

\section{Technicians}

One of the problems identified in schools is the repair and service of computers. Teacher training should include a basic understanding of how a computer works so teachers can acquire skills for first-line maintenance, be able to service the computers, and correct simple software and hardware problems. Major problems can be referred to trained technicians.

\section{THE ZIMBABWE MIDLANDS INFORMATION TECHNOLOGY IN EDUCATION PROJECT}

\subsection{Project description}

The Zimbabwe Midlands Information Technology in Education Project (ZiMITEP) is a pilot research project meant to provide solutions to many of the problems that inhibit systematic capacity building for IT in developing countries in education. The interests and contributions of all stakeholders in the field of education will be considered. Stakeholders include government, represented by the Ministry of Education, parents, teachers, the private sector, universities and teachers' colleges as well as the Computer Society of Zimbabwe.

The management of the project is flexible to allow schools to experiment with the independent, dependent, moderator and control variables being monitored to ensure the best result from the pilot research project.

\subsection{Objectives of the project}

In view of the situation in the sub-region in general and Zimbabwe in particular the project has been designed to:

- bring together and harmonize IT activities in the schools;

- $\quad$ promote and coordinate in-service training in IT in Zimbabwe;

- seek to cooperate with other local and external organizations for the purpose of exchanging and sharing ideas and experiences;

- provide some solutions to problems and obstacles encountered in the introduction of IT in developing countries;

- $\quad$ provide a base for the systematic implementation of IT in schools; 
- $\quad$ provide the Ministry of Education with researched information for capacity building and national policy in IT.

\subsection{Implementation and location}

The ZiMITEP project is being implemented in the Midlands Province, which is the third-largest province in terms of the number of schools and enrolments. Midlands has 226 secondary and 640 primary schools for a total of 866 Schools $13.6 \%$ of the 6187 schools in Zimbabwe. The 443986 students in the province represent $14 \%$ of the total school population. The Midlands Province has a total of 12579 Teachers - 13.6\% of 92554 teachers in Zimbabwe in 1996.

The Midlands is an ideal province for the pilot project because it is representative of Zimbabwe as a whole in terms of type of school environment. Urban, rural mining and farming communities are found in the province so it represents all the possible social, cultural, political and economic settings found in Zimbabwe. The Midlands Province is also unique in that it has the largest number of rural schools with electricity. The Information Technology project will also be used as a motivating factor for those schools without electricity.

\section{Phase 1}

Phase 1 of the project will include a minimum of 16 primary and secondary schools - government, mission and private - spread over the province. Each school's variables are being analyzed for the appropriate input and intervention.

\section{Phase 2}

Phase 2 will include more schools, including schools outside the province which have acquired computers. Radio and television broadcasts, and interviews on the project will encourage more schools to acquire computers.

\section{Phase 3}

Phase 3 will involve analysis of results from the pilot schools and the production of a report. The material that will be produced may be used for teaching IT at the national level.

\subsection{Project management}

The project will be managed at three levels - the school, the district and the provincial level.

\section{School committee}

The school committee is made up of the teachers and parents (students may be included), and the committee is responsible for the day-to-day running of the project. 


\section{District committee}

Teachers from each of the pilot schools in the same district participate in the district committee. They hold regular meetings to share ideas and school experiences.

\section{Provincial committee}

Overall management and policy rests with the provincial committee which is responsible for planning implementation and research strategies. The committee has representatives from the District Office, Regional Office, Head Office, Curriculum Development Unit and the Computer Society of Zimbabwe.

\subsection{Project activities}

The project encompasses the following activities:

- identification of the sample schools in the project;

- curriculum research, development and diffusion;

- in-service teacher training;

- fund-raising for hardware and software;

- Internet and networking;

- establishing resource and service centres;

- popularizing Information Technology.

Production of support materials and basic materials has provided the required support materials resources.

\subsection{In-service teacher training}

Information technology is an innovation in our schools. Therefore in-service training should be viewed as an intervention to facilitate the diffusion of the innovation. Two models - A and B - will be used in the ZiMITEP project.

Model A has been used for teachers in the province who do not have computers at their schools. The teachers will be trained during school vacations and over weekends by going to a Resource Centre for their practical experience. They will receive learning materials for the theory part of the course to study during the term at their places of work. The model has been tried with over 300 teachers who have successfully completed the one year in-service Distance Education course which has proved to be a success. Urban teachers can attend lessons during the day or evening.

Model B has been used for schools which have or will have been given computers. The teachers receive their training at their schools at appropriate times. The teachers may sit for Certificate or Diploma Examinations to motivate them with recognized qualification. Training will include evaluation of educational software to take care of the differences in social and cultural values which are likely to be enshrined in the foreign-produced software.

The present in-service curriculum includes:

- Information Technology concepts; 
- computer operations and packages;

- introduction to database management;

- Information Technology in education;

- curriculum development.

\section{Curriculum development}

The project will assist the Ministry of Education in the development of an appropriate curriculum for secondary and primary schools through the Research, Development and Diffusion (RDD) model. The basis of the curriculum will be computer literacy, the application of computer tools in other subject areas and the application of computers in professional areas.

The development of the curriculum will be done in consultation with other schools in the country teaching computers in conjunction with universities, commerce and industry. Innovation and creativity will be encouraged since the above suggestions were recommended by the International Federation for Information Processing (IFIP) Technical Committee on Education (TC3) Working Group (WG 3.1) sponsored by UNESCO (Tinsley and van Weert, 1994) to guide curriculum developers.

\section{Internet Networking}

The project will establish Internet connections so that schools can talk to each other and link with other schools outside Zimbabwe. This will be an instance of using computers as resources and communication devices.

\subsection{Acquisition of hardware and software}

The project will assist the pilot schools to acquire hardware and software through donors such as local companies. Schools are also encouraged to solicit donations through parents. Community commitment will be sought before schools can be given computer equipment.

\section{Information Technology awareness}

The project management committee will hold meetings with policy and decision makers to ensure their involvement so that they appreciate the value of IT in education. Meetings will be held with the parents so that they accept ownership of the equipment to ensure sustenance of the programme beyond the life of the project.

\section{Establishment of IT Resource and Service Centres}

Some of the schools that are centrally located and have separate computer rooms will be established as Resource and Services Centres where other teachers may utilize the facilities. Some teachers who are programmers will be encouraged to produce educational software. A joint venture will be encouraged between the private sector and the government in the production of the educational software. 


\subsection{Monitoring and evaluation}

The Management Committee is using the Context, Input, Process, Product and Impact (CIPPI) Evaluation Model to control and monitor variables.

The context component has identified the number of teachers in the province qualified to teach IT and the number of schools with computers. Data has also been collected on the number and status of hardware in schools as well as data on the social, economic and political of environment of each implementing school.

Input includes the fact that the schools require state-of-the-art equipment in order to teach computers across the curriculum or be connected to other schools' resources.

Process evaluation occurs as every activity is being monitored to record the teachers' assessment and students' reactions, which are being shared by the teachers in the project.

Product evaluation means that at end of the project, the results will be measured to assess the replicability of the project.

\section{$4 \quad$ CONCLUSION}

It is expected that the pilot project will provide valuable experiences, knowledge and skills in the systematic implementation of IT in education in Zimbabwe and the neighboring developing countries. Some of the most important components of the pilot project relate to the involvement of all stakeholders in education to ensure sustainability and continuity of capacity building in terms of equipment and human resources training.

\section{REFERENCES}

Tinsley, J.D. and van Weert, T.J. (eds.) (1994) Informatics for Secondary

Education, A Curriculum for Schools. UNESCO, Paris.

Sam D. Gumbo is the director of Computer Education Services, a company involved in the training of teachers through in-service distance and open learning activities. He is a member of various committees on IT in education, including the UNESCO committee on Inter-governmental Informatics. He is also on the Education Committee of the Computer Society of Zimbabwe. 